\title{
Development of Sulfonamide Photoaffinity Inhibitors for Probing Cellular $\gamma$-Secretase
}

Christina J. Crump, ${ }^{+, t, \pi}$ Heather E. Murrey,,$*$ T. Eric Ballard, ${ }^{, \bullet}$ Christopher W. am Ende, Xianzhong Wu, ${ }^{\dagger}$ Natalya Gertsik, ${ }^{+,}$Douglas S. Johnson, ${ }^{*} "$ and Yue-Ming $\mathrm{Li}^{*}+,+$,

Chemical Biology Program, Memorial Sloan Kettering Cancer Center, 1275 York Avenue, New York, New York 10065, United States

${ }^{\ddagger}$ Program of Pharmacology and ${ }^{\S}$ Biochemistry and Molecular Biology Program, Weill Graduate School of Medical Sciences, Cornell University, New York, New York 10021, United States

„Pfizer Worldwide Research and Development, Worldwide Medicinal Chemistry, Cambridge, Massachusetts 02139 , United States

${ }_{\lrcorner}$Pfizer Worldwide Research and Development, Worldwide Medicinal Chemistry Groton, Connecticut 06340, United States.

\section{Supplemental Figures}

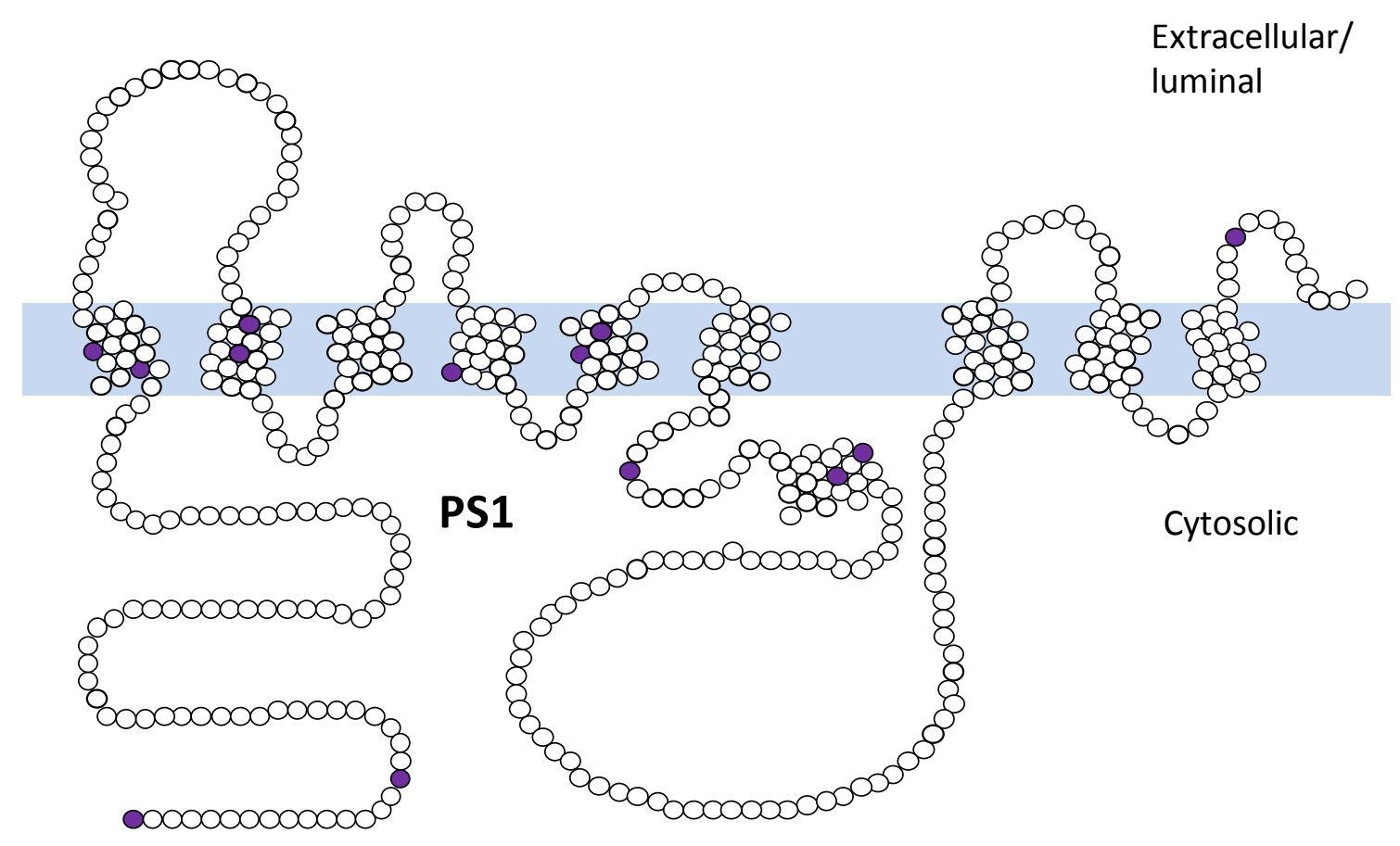

Supplemental Figure 1. Schematic representation of PS1 with the 13 methionine residues marked by purple solid circles at positions of 1, 16, 84, 93, 139, 146, 210, 228, 233, 270, 292, 298 and 457. 


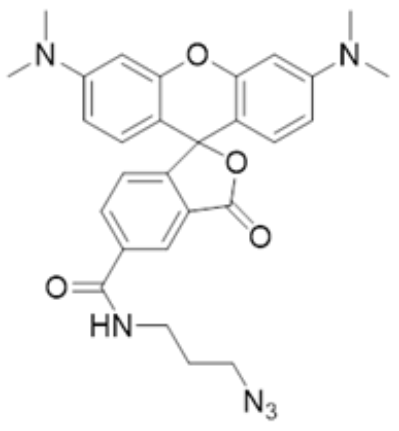

Supplemental Figure 2. Structure of TAMRA-azide

General Information: All commercially available reagents and solvents were used as received. Reactions were monitored by thin layer chromatography (TLC) performed on Analtech, Inc. silica gel GF $250 \mu \mathrm{m}$ plates and were visualized with ultraviolet (UV) light (254 nm), $\mathrm{KMnO}_{4}$ and/or ninhydrin staining or by UPLC-MS (Waters Acquity, ESCI (ESI +/-, APCI +/-). Silica gel flash chromatography was performed with RediSep Rf or Biotage disposable normal phase silica gel flash columns on a CombiFlash Rf system from Teledyne Isco, Inc. or a Biotage Horizon automatic purification system. Proton, Carbon and Fluorine nuclear magnetic resonance $\left({ }^{1} \mathrm{H} N M R,{ }^{13} \mathrm{C} \mathrm{NMR}\right.$ and $\left.{ }^{19} \mathrm{~F} \mathrm{NMR}\right)$ spectra were recorded on a Varian-Inova $400(400 \mathrm{MHz}, 101 \mathrm{MHz}$ and $377 \mathrm{MHz}$, respectively), Varian-Inova $600(600 \mathrm{MHz}$ and $151 \mathrm{MHz}$, respectively), a Bruker 400 (400 MHz, $101 \mathrm{MHz}$ and $377 \mathrm{MHz}$, respectively), or a Bruker 500 (500 MHz and $126 \mathrm{MHz}$, respectively) spectrometer. Chemical shifts are reported in ppm relative to $\mathrm{CHCl}_{3}$ or $\mathrm{MeOH}$ (i.e. ${ }^{1} \mathrm{H}$ NMR $\delta=7.26$ and ${ }^{13} \mathrm{C}$ NMR $\delta=77.0$ or ${ }^{1} \mathrm{H}$ NMR $\delta=3.31$ and ${ }^{13} \mathrm{C}$ NMR $\delta=49.1$, respectively). The peak shapes are denoted as follows: $s$, singlet; $d$, doublet; $t$, triplet; $q$, quartet; $m$, multiplet; br., broad. High-resolution mass spectra (HRMS) were acquired on an Agilent model 6220 time-of-flight (TOF) mass spectrometer in positive or negative electrospray ionization (ESI) mode.

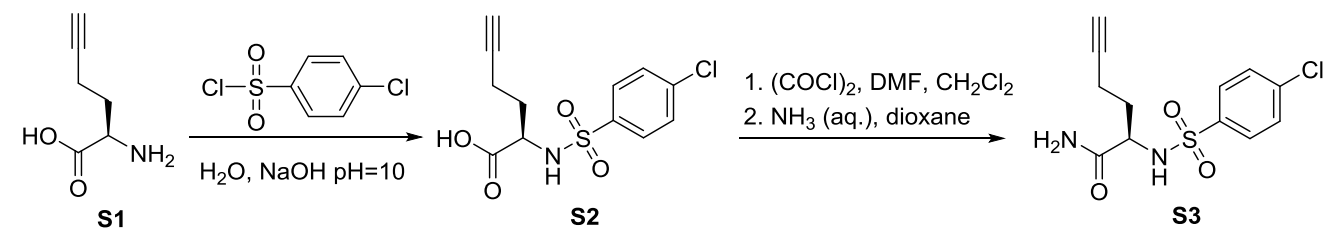

(R)-2-(4-chlorophenylsulfonamido)hex-5-ynoic acid (S2): D-Homopropargylglycine $\mathbf{S 1}^{1}$ (1500 mg, 11.8 $\mathrm{mmol}$ ) and 4-chlorobenzenesulphonyl chloride (3480 mg, $16.5 \mathrm{mmol}$ ) were dissolved in deionized water 
(175 $\mathrm{mL}$ ) under a nitrogen atmosphere. $1 \mathrm{M} \mathrm{NaOH}$ was added until $\mathrm{pH} 10$ was reached. The mixture was allowed to react for 16 hours at room temperature kept at $\mathrm{pH} 10$ with $1 \mathrm{M} \mathrm{NaOH}$. The clear mixture was washed with tert-butylmethylether $(2 \times 10 \mathrm{~mL})$. The aqueous layer was then acidified to $\mathrm{pH} 2-3 \mathrm{using} 1 \mathrm{~N}$ $\mathrm{HCl}$, extracted with EtOAc $(2 \times 45 \mathrm{~mL})$. The combined organics were washed with water $(20 \mathrm{~mL})$ and brine $\left(20 \mathrm{~mL}\right.$ ) before being dried with anhydrous $\mathrm{Na}_{2} \mathrm{SO}_{4}$, filtered and concentrated under reduced pressure to afford the title compound $\mathbf{S 2}(2800 \mathrm{mg}, 79 \%)$ as an off-white solid. This material was used in the next step without further purification.

(R)-2-(4-chlorophenylsulfonamido)hex-5-ynamide (S3): To a solution of $\mathbf{S 2}$ (2800 $\mathrm{mg}, 9.3 \mathrm{mmol}$ ) in $\mathrm{CH}_{2} \mathrm{Cl}_{2}\left(50 \mathrm{~mL}\right.$ ) was added oxalyl chloride (2M solution in $\mathrm{CH}_{2} \mathrm{Cl}_{2}, 2.5 \mathrm{~mL}, 18.6 \mathrm{mmol}$ ) and DMF (3 drops) and the solution was heated to reflux for 30 minutes. The solution was evaporated to dryness and the crude acid chloride was solvated into dioxanes $(10 \mathrm{~mL})$ then $\mathrm{NH}_{4} \mathrm{OH}(\mathrm{aq})(1.24 \mathrm{~mL}, 46.5 \mathrm{mmol})$ was added and the mixture was allowed to stir for 48 hours. Upon completion, the solution was evaporated to dryness and solvated with EtOAc/THF $(2: 3,60 \mathrm{~mL})$ and was washed with water $(10 \mathrm{~mL})$ and brine (10 $\mathrm{mL}$ ) before being dried with anhydrous $\mathrm{Na}_{2} \mathrm{SO}_{4}$, filtered and concentrated under reduced pressure to afford the title compound $\mathbf{S 3}$ (2000 mg, 71\%) as an off-white solid. ${ }^{1} \mathrm{H}$ NMR (400 MHz, DMSO- $\left.d_{6}\right) \delta 8.06$ $(\mathrm{s}, 1 \mathrm{H}), 7.77(\mathrm{~d}, J=8.6,2 \mathrm{H}), 7.62(\mathrm{~d}, J=8.6,2 \mathrm{H}), 7.29(\mathrm{~s}, 1 \mathrm{H}), 7.03(\mathrm{~s}, 1 \mathrm{H}), 3.71,(\mathrm{~m}, 1 \mathrm{H}), 2.73(\mathrm{~m}, 1 \mathrm{H})$, $2.05(\mathrm{~m}, 2 \mathrm{H}), 1.71(\mathrm{~m}, 1 \mathrm{H}), 1.57(\mathrm{~m}, 1 \mathrm{H})$; HPLC Purity: 96\%.

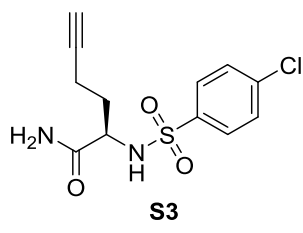

S3

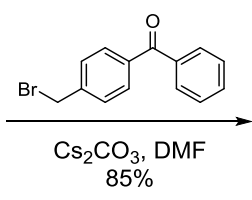

$85 \%$

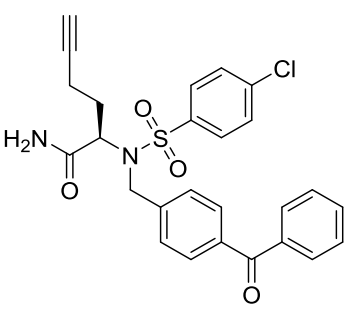

163-BP1 (163-BPyne)

(R)-2-(N-(4-benzoylbenzyl)-4-chlorophenylsulfonamido)hex-5-ynamide (163-BP1/163-BPyne) ${ }^{1}$ : Alkynyl sulfonamide $\mathbf{S} 3$ (26 mg, $0.086 \mathrm{mmol})$ was dissolved in anhydrous DMF $(0.5 \mathrm{~mL})$ and cooled to $0{ }^{\circ} \mathrm{C}$. To this solution was added 4-(bromomethyl)-benzophenone $(26.1 \mathrm{mg}, 0.095 \mathrm{mmol})$ and $\mathrm{Cs}_{2} \mathrm{CO}_{3}(36.9 \mathrm{mg}$, $0.112 \mathrm{mmol}$ ) and the solution was then warmed to room temperature. The reaction was judged complete by TLC analysis ( 16 hours) and the reaction mixture was diluted with EtOAc $(10 \mathrm{~mL})$ and washed with water $(10 \mathrm{~mL})$. The aqueous layer was back-extracted with EtOAc $(3 \times 5 \mathrm{~mL})$ and the combined organics were washed with water $(10 \mathrm{~mL}), 1 \mathrm{M} \mathrm{LiCl}(10 \mathrm{~mL})$ and brine $(10 \mathrm{~mL})$ before being dried with anhydrous $\mathrm{Na}_{2} \mathrm{SO}_{4}$, filtered and concentrated under reduced pressure. The resulting oil was purified by silica gel flash column chromatography eluting with EtOAc/Heptane $(10-50 \%)$ to afford the title compound 163-BP1 (36 mg, 85\%) as an off-white solid: ${ }^{1} \mathrm{H}$ NMR (400 MHz, $\left.\mathrm{CDCl}_{3}\right) \delta 7.79-7.70(\mathrm{~m}$, $6 \mathrm{H}), 7.59$ (tt, $J=6.7,1.4 \mathrm{~Hz}, 1 \mathrm{H}), 7.50-7.41(\mathrm{~m}, 6 \mathrm{H}), 6.37$ (bs, $1 \mathrm{H}), 5.59$ (bs, $1 \mathrm{H}), 4.60$ (dd, J = 8.6, $5.5 \mathrm{~Hz}$, $1 \mathrm{H}), 4.62(\mathrm{~d}, J=15.7 \mathrm{~Hz}, 1 \mathrm{H}), 4.51(\mathrm{~d}, J=16.0 \mathrm{~Hz}, 1 \mathrm{H}), 2.21-2.07(\mathrm{~m}, 3 \mathrm{H}), 2.01-1.97(\mathrm{~m}, 1 \mathrm{H}), 1.52-$ $1.38(\mathrm{~m}, 1 \mathrm{H}) ;{ }^{13} \mathrm{C} \mathrm{NMR}\left(100 \mathrm{MHz}, \mathrm{CDCl}_{3}\right) \delta 196.1,170.8,140.8,139.8,138.1,137.4,137.1,132.5,130.3$, 130.0, 129.6, 128.7, 128.5, 128.3, 82.4, 70.3, 58.0, 48.5, 27.8, 15.5; HRMS calcd for $\mathrm{C}_{26} \mathrm{H}_{24} \mathrm{CIN}_{2} \mathrm{O}_{4} \mathrm{~S}(\mathrm{M}+\mathrm{H})$ 495.1140, found 495.1126; HPLC Purity: 99\%. 

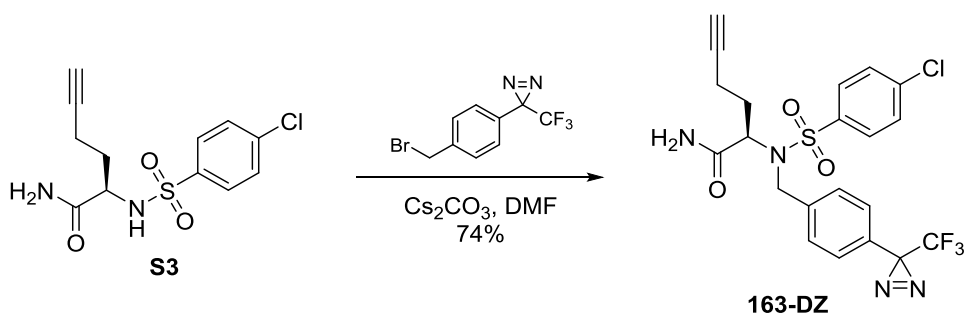

(R)-2-((4-chloro-N-(4-(3-(trifluoromethyl)-3H-diazirin-3-yl)benzyl)phenyl)sulfonamido)hex-5-ynamide (163-DZ): To a solution of alkynyl sulfonamide $\mathbf{S 3}$ (100 mg, $0.33 \mathrm{mmol}$ ) and 3-(4-(bromomethyl)phenyl)3-(trifluoromethyl)-3H-diazirine ${ }^{2}\left(111 \mathrm{mg}, 0.398 \mathrm{mmol}\right.$ ) in anhydrous DMF (3.3 mL) was added $\mathrm{Cs}_{2} \mathrm{CO}_{3}$ (131 $\mathrm{mg}, 0.398 \mathrm{mmol})$. The reaction mixture was stirred at room temperature for 19 hours. EtOAc (10 $\mathrm{mL}$ ) was added and the mixture was washed with water $(3 \times 10 \mathrm{~mL})$. The organic fraction was dried with anhydrous $\mathrm{Na}_{2} \mathrm{SO}_{4}$, filtered and concentrated under reduced pressure. The crude residue was purified by silica gel flash chromatography eluting with EtOAc/heptane $(0-80 \%)$ to afford the title compound 163-DZ (122 mg, 74\% yield) as a white solid. ${ }^{1} \mathrm{H}$ NMR (400 MHz, $\left.\mathrm{CDCl}_{3}\right) \delta 7.71-7.65(\mathrm{~m}, 2 \mathrm{H}), 7.48-7.42$ $(\mathrm{m}, 2 \mathrm{H}), 7.35$ (d, $J=8.4 \mathrm{~Hz}, 2 \mathrm{H}$ ), 7.11 (d, $J=8.2 \mathrm{~Hz}, 2 \mathrm{H}$ ), 6.30 (br. s., $1 \mathrm{H}$ ), 5.22 (br. s., $1 \mathrm{H}$ ), 4.59 (dd, $J=5.4$, $8.6 \mathrm{~Hz}, 1 \mathrm{H}), 4.57-4.37(\mathrm{~m}, 2 \mathrm{H}), 2.21-2.13(\mathrm{~m}, 1 \mathrm{H}), 2.13-2.06(\mathrm{~m}, 2 \mathrm{H}), 1.99(\mathrm{t}, J=2.5 \mathrm{~Hz}, 1 \mathrm{H}), 1.45-$ 1.35 (m, 1H); LRMS (M+H) 499.1; HPLC Purity: > 99\%.

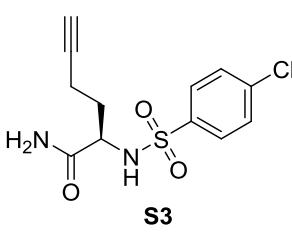

S3
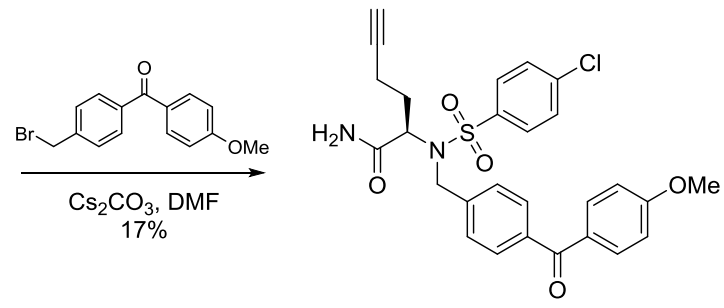

163-BP1-OMe

(R)-2-(4-chloro-N-(4-(4-methoxybenzoyl)benzyl)phenylsulfonamido)hex-5-ynamide (163-BP1-OMe):

Alkynyl sulfonamide $\mathbf{S 3}(163 \mathrm{mg}, 0.54 \mathrm{mmol})$ was dissolved in anhydrous DMF $(3 \mathrm{~mL})$ and cooled to $0{ }^{\circ} \mathrm{C}$. To this solution was added 4-(bromomethyl)-4'-methoxybenzophenone ${ }^{3}(150 \mathrm{mg}, 0.49 \mathrm{mmol}$ ) and $\mathrm{Cs}_{2} \mathrm{CO}_{3}(322 \mathrm{mg}, 0.99 \mathrm{mmol}$ ) and the solution was then warmed to room temperature. The reaction was judged complete by TLC analysis ( 16 hours) and the reaction mixture was diluted with EtOAc $(10 \mathrm{~mL})$ and washed with water $(10 \mathrm{~mL})$. The aqueous layer was back-extracted with EtOAc $(3 \times 5 \mathrm{~mL})$ and the combined organics were washed with water $(10 \mathrm{~mL}), 1 \mathrm{M} \mathrm{LiCl}(10 \mathrm{~mL})$ and brine $(10 \mathrm{~mL})$ before being dried with anhydrous $\mathrm{Na}_{2} \mathrm{SO}_{4}$, filtered and concentrated under reduced pressure. The resulting oil was purified by silica gel flash column chromatography eluting with EtOAc/Heptane $(10-50 \%)$ to afford the title compound 163-BP1-OMe (45 mg, 17\%) as an off-white solid: ${ }^{1} \mathrm{H}$ NMR $\left(400 \mathrm{MHz}, \mathrm{CDCl}_{3}\right) \delta 7.79(\mathrm{~d}, J=$ $8.6 \mathrm{~Hz}, 2 \mathrm{H}), 7.74(\mathrm{~d}, J=8.6 \mathrm{~Hz}, 2 \mathrm{H}), 7.67(\mathrm{~d}, J=8.0 \mathrm{~Hz}, 2 \mathrm{H}), 7.47(\mathrm{~d}, J=8.4 \mathrm{~Hz}, 2 \mathrm{H}), 7.42(\mathrm{~d}, J=8.0 \mathrm{~Hz}, 2 \mathrm{H})$, $6.96(\mathrm{~d}, J=8.6 \mathrm{~Hz}, 2 \mathrm{H}), 6.37(\mathrm{bs}, 1 \mathrm{H}), 5.52(\mathrm{bs}, 1 \mathrm{H}), 4.69-4.45(\mathrm{~m}, 3 \mathrm{H}), 3.88(\mathrm{~s}, 3 \mathrm{H}), 2.25-2.06(\mathrm{~m}, 3 \mathrm{H})$, $1.99(\mathrm{t}, J=2.2 \mathrm{~Hz}, 1 \mathrm{H}), 1.54-1.37(\mathrm{~m}, 1 \mathrm{H}) ;{ }^{13} \mathrm{C} \mathrm{NMR}\left(100 \mathrm{MHz}, \mathrm{CDCl}_{3}\right) \delta 194.9,170.8,163.3,140.1$, 139.8, 138.1, 137.8, 132.5, 129.9, 129.6, 128.7, 128.5, 113.6, 82.4, 70.3, 58.0, 55.5, 48.5, 27.8, 15.5; HRMS calcd for $\mathrm{C}_{27} \mathrm{H}_{26} \mathrm{ClN}_{2} \mathrm{O}_{5} \mathrm{~S}(\mathrm{M}+\mathrm{H}) 525.1245$, found 525.1238; HPLC Purity: $98 \%$. 


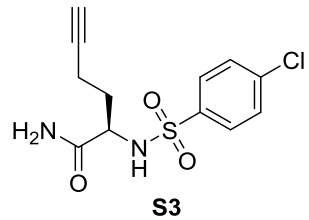

s3
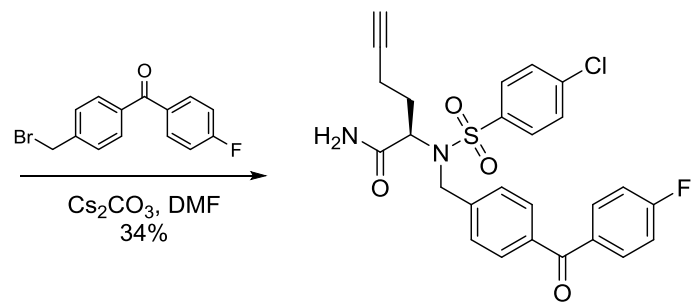

163-BP1-F

(R)-2-(4-chloro-N-(4-(4-fluorobenzoyl)benzyl)phenylsulfonamido)hex-5-ynamide (163-BP1-F): Alkynyl sulfonamide $\mathbf{S} 3$ (56.3 $\mathrm{mg}, 0.188 \mathrm{mmol}$ ) was dissolved in anhydrous DMF (1 mL) and cooled to $0{ }^{\circ} \mathrm{C}$. To this solution was added 4-(bromomethyl)-4'-fluorobenzophenone ${ }^{4}(50 \mathrm{mg}, 0.175 \mathrm{mmol})$ and $\mathrm{Cs}_{2} \mathrm{CO}_{3}(110$ $\mathrm{mg}, 0.34 \mathrm{mmol}$ ) and the solution was then warmed to room temperature. The reaction was judged complete by TLC analysis ( 16 hours) and the reaction mixture was diluted with EtOAc $(10 \mathrm{~mL})$ and washed with water $(10 \mathrm{~mL})$. The aqueous layer was back-extracted with EtOAc $(3 \times 5 \mathrm{~mL})$ and the combined organics were washed with water $(10 \mathrm{~mL}), 1 \mathrm{M} \mathrm{LiCl}(10 \mathrm{~mL})$ and brine $(10 \mathrm{~mL})$ before being dried with anhydrous $\mathrm{Na}_{2} \mathrm{SO}_{4}$, filtered and concentrated under reduced pressure. The resulting oil was purified by silica gel flash column chromatography eluting with EtOAc/Heptane (10-50\%) to afford the title compound 163-BP1-F (30 mg, 34\%) as an off-white solid: $\left.{ }^{1} \mathrm{H} \mathrm{NMR} \mathrm{(400} \mathrm{MHz,} \mathrm{CDCl}_{3}\right) \delta 7.86-7.78$ (m, $2 \mathrm{H}), 7.78-7.72(\mathrm{~m}, 2 \mathrm{H}), 7.72-7.66(\mathrm{~m}, 2 \mathrm{H}), 7.51-7.42(\mathrm{~m}, 4 \mathrm{H}), 7.20-7.13(\mathrm{~m}, 2 \mathrm{H}), 6.36(\mathrm{bs}, 1 \mathrm{H}), 5.43$ (bs, $1 \mathrm{H}), 4.70-4.55(\mathrm{~m}, 2 \mathrm{H}), 4.55-4.46(\mathrm{~m}, 1 \mathrm{H}), 2.23-2.07(\mathrm{~m}, 3 \mathrm{H}), 2.02-1.98(\mathrm{~m}, 1 \mathrm{H}), 1.50-1.38(\mathrm{~m}$, $1 \mathrm{H}) ;{ }^{13} \mathrm{C} \mathrm{NMR}\left(100 \mathrm{MHz}, \mathrm{CDCl}_{3}\right) \delta 194.6,170.6,165.4$ (d, $\left.J_{C F}=253 \mathrm{~Hz}\right), 140.8,139.9,138.1,137.0,133.6$ (d, $J_{C F}=2.8 \mathrm{~Hz}$ ), $132.6\left(\mathrm{~d}, J_{C F}=9.5 \mathrm{~Hz}\right.$ ), 130.1, 129.6, 128.7, 128.6, 115.5 (d, $\left.J_{C F}=22 \mathrm{~Hz}\right), 82.4,70.3,57.9$, 48.5, 27.7, 15.5; ${ }^{19} \mathrm{~F} \mathrm{NMR} \mathrm{(377} \mathrm{MHz,} \mathrm{CDCl} 3$ ) $\delta-105.6$ (s, 1F); HRMS calcd for $\mathrm{C}_{26} \mathrm{H}_{23} \mathrm{ClFN}_{2} \mathrm{O}_{4} \mathrm{~S}(\mathrm{M}+\mathrm{H})$ 513.1046, found 513.1031; HPLC Purity: $87 \%$.

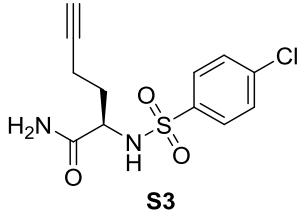

S3

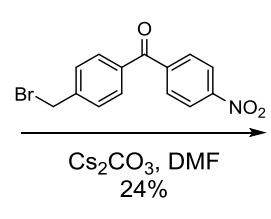
$24 \%$

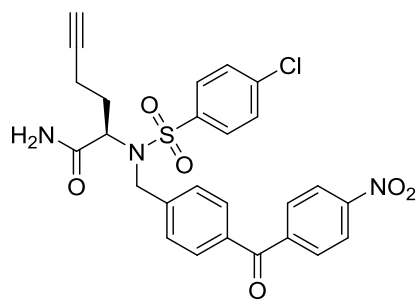

163-BP1- $\mathrm{NO}_{2}$

(R)-2-(4-chloro-N-(4-(4-nitrobenzoyl)benzyl)phenylsulfonamido)hex-5-ynamide (163-BP1-NO 2 ): Alkynyl sulfonamide $\mathbf{S} 3(86.7 \mathrm{mg}, 0.29 \mathrm{mmol})$ was dissolved in anhydrous DMF $(2 \mathrm{~mL})$ and cooled to $0{ }^{\circ} \mathrm{C}$. To this solution was added 4-(bromomethyl)-4'-nitrobenzophenone ${ }^{5}\left(85 \mathrm{mg}, 0.27 \mathrm{mmol}\right.$ ) and $\mathrm{Cs}_{2} \mathrm{CO}_{3}(173 \mathrm{mg}$, $0.53 \mathrm{mmol}$ ) and the solution was then warmed to room temperature. The reaction was judged complete by TLC analysis ( 16 hours) and the reaction mixture was diluted with EtOAc $(10 \mathrm{~mL})$ and washed with water $(10 \mathrm{~mL})$. The aqueous layer was back-extracted with EtOAc $(3 \times 5 \mathrm{~mL})$ and the combined organics were washed with water $(10 \mathrm{~mL}), 1 \mathrm{M} \mathrm{LiCl}(10 \mathrm{~mL})$ and brine $(10 \mathrm{~mL})$ before being dried with anhydrous $\mathrm{Na}_{2} \mathrm{SO}_{4}$, filtered and concentrated under reduced pressure. The resulting oil was purified by silica gel flash column chromatography eluting with EtOAc/Heptane $(10-50 \%)$ to afford the title compound 163BP1-NO 2 (35 mg, 24\%) as an off-white solid: ${ }^{1} \mathrm{H} \mathrm{NMR}\left(400 \mathrm{MHz}, \mathrm{CDCl}_{3}\right) \delta 8.27(\mathrm{~d}, J=8.6 \mathrm{~Hz}, 2 \mathrm{H}), 7.84(\mathrm{~d}, J$ 
$=8.6 \mathrm{~Hz}, 2 \mathrm{H}), 7.71(\mathrm{~d}, J=8.6 \mathrm{~Hz}, 2 \mathrm{H}), 7.67(\mathrm{~d}, J=8.2 \mathrm{~Hz}, 2 \mathrm{H}), 7.43(\mathrm{~d}, J=8.2 \mathrm{~Hz}, 4 \mathrm{H}), 6.28(\mathrm{bs}, 1 \mathrm{H}), 5.30$ (bs, $1 \mathrm{H}), 4.61(\mathrm{~d}, J=16.0 \mathrm{~Hz}, 1 \mathrm{H}), 4.57-4.52(\mathrm{~m}, 1 \mathrm{H}), 4.42(\mathrm{~d}, J=16.0 \mathrm{~Hz}, 1 \mathrm{H}), 2.16-2.00(\mathrm{~m}, 3 \mathrm{H}), 1.97-$ $1.92(\mathrm{~m}, 1 \mathrm{H}), 1.42-1.30(\mathrm{~m}, 1 \mathrm{H}) ;{ }^{13} \mathrm{C} N M R\left(100 \mathrm{MHz}, \mathrm{CDCl}_{3}\right) \delta 194.2,170.5,149.9,142.7,142.1,140.0$, 138.0, 135.8, 130.7, 130.3, 129.7, 128.8, 128.7, 123.6, 82.3, 70.4, 57.8, 48.4, 27.7, 15.5; HRMS calcd for $\mathrm{C}_{26} \mathrm{H}_{23} \mathrm{CIN}_{3} \mathrm{O}_{6} \mathrm{~S}(\mathrm{M}+\mathrm{H})$ 540.0991, found 540.0972; HPLC Purity: $97 \%$.

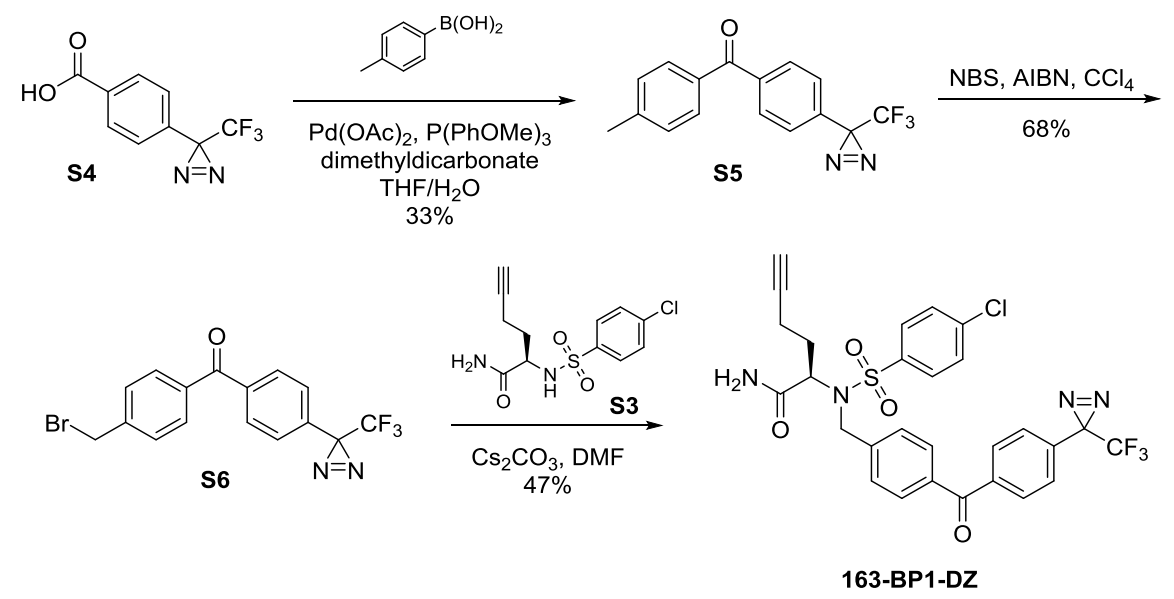

p-tolyl(4-(3-(trifluoromethyl)-3H-diazirin-3-yl)phenyl)methanone (S5): 4-(3-(Trifluoromethyl)-3Hdiazirin-3-yl)benzoic acid $\mathbf{S 4}(536 \mathrm{mg}, 2.33 \mathrm{mmol})$ was dissolved in THF $(11.6 \mathrm{~mL})$ and brought to $0{ }^{\circ} \mathrm{C}$. To the solution was added $p$-tolylboronic acid $(380 \mathrm{mg}, 2.80 \mathrm{mmol})$, followed by $\mathrm{P}(\mathrm{PhOMe})_{3}(60.5 \mathrm{mg}, 0.163$ $\mathrm{mmol})$, dimethyldicarbonate $(625 \mathrm{mg}, 4.66 \mathrm{mmol})$, and then $\mathrm{Pd}(\mathrm{OAc})_{2}(16.2 \mathrm{mg}, 0.07 \mathrm{mmol})$. Water (0.11 $\mathrm{mL}$ ) was added and the solution was degassed with nitrogen for 5 minutes at this temperature. The solution was brought to room temperature and stirred overnight. The solution became dark overnight and was then diluted with EtOAc $(50 \mathrm{~mL})$ and water $(50 \mathrm{~mL})$. The organic fraction was washed with water $(50 \mathrm{~mL})$, and then brine $(50 \mathrm{~mL})$. The organic fraction was dried over anhydrous $\mathrm{Na}_{2} \mathrm{SO}_{4}$, filtered, and concentrated under reduced pressure. The crude residue was purified by silica gel flash chromatography eluting with $\mathrm{CH}_{2} \mathrm{Cl}_{2} /$ heptane $(0-50 \%)$ to afford the title compound $\mathbf{S 5}$ (232 $\mathbf{~ m g , ~ 3 3 \% ~}$ yield) as a beige solid. ${ }^{1} \mathrm{H} N M R\left(400 \mathrm{MHz}, \mathrm{CDCl}_{3}\right) \delta 7.84-7.77(\mathrm{~m}, 2 \mathrm{H}), 7.73-7.65(\mathrm{~m}, 2 \mathrm{H}), 7.29(\mathrm{~d}, J=$ $8.3 \mathrm{~Hz}, 4 \mathrm{H}), 2.45(\mathrm{~s}, 3 \mathrm{H})$.

(4-(bromomethyl)phenyl)(4-(3-(trifluoromethyl)-3H-diazirin-3-yl)phenyl)methanone (S6): A solution of S5 $(0.232 \mathrm{~g}, 0.762 \mathrm{mmol})$ in $\mathrm{CCl}_{4}(3.05 \mathrm{~mL})$ was heated to $70{ }^{\circ} \mathrm{C}$ and freshly recrystalized $\mathrm{N}$ bromosuccinimide $(0.164 \mathrm{~g}, 0.914 \mathrm{mmol})$ was added and stirred for $10 \mathrm{~min}$, then AIBN $(3.0 \mathrm{mg}, 0.0108$ $\mathrm{mmol}$ ) was added and the reaction was refluxed for 2 hours. A precipitate formed and was filtered, and washed with $\mathrm{CH}_{2} \mathrm{Cl}_{2}$. The filtrate was concentrated under reduced pressure to afford a white residue. The residue was purified by silica gel flash chromatography eluting with $5 \% \mathrm{CH}_{2} \mathrm{Cl}_{2}$ in heptane to afford S6 (199 mg, 68\%) as a white solid. ${ }^{1} \mathrm{H}$ NMR (400 MHz, $\left.\mathrm{CDCl}_{3}\right) \delta 7.84-7.79(\mathrm{~m}, 2 \mathrm{H}), 7.78-7.72(\mathrm{~m}, 2 \mathrm{H})$, $7.55-7.47(\mathrm{~m}, 2 \mathrm{H}), 7.34-7.27(\mathrm{~m}, 2 \mathrm{H}), 4.53(\mathrm{~s}, 2 \mathrm{H})$; LRMS $(\mathrm{M}+\mathrm{H}) 383.1$.

(R)-2-((4-chloro-N-(4-(4-(3-(trifluoromethyl)-3H-diazirin-3-yl)benzoyl)benzyl)phenyl)sulfonamido)hex5-ynamide (163-BP1-DZ): To a solution of alkynyl sulfonamide $\mathbf{S 3}$ (71 $\mathrm{mg}, 0.24 \mathrm{mmol}$ ) and $\mathbf{S 6}$ (90 mg, $0.24 \mathrm{mmol})$ in anhydrous DMF $(2.4 \mathrm{~mL})$ was added $\mathrm{Cs}_{2} \mathrm{CO}_{3}(93 \mathrm{mg}, 0.28 \mathrm{mmol})$. The reaction mixture 
was stirred at room temperature for 17 hours. EtOAc $(10 \mathrm{~mL})$ was added and the mixture was washed with water $(3 \times 10 \mathrm{~mL})$. The organic fraction was dried with anhydrous $\mathrm{Na}_{2} \mathrm{SO}_{4}$, filtered and concentrated under reduced pressure. The crude residue was purified by silica gel flash chromatography eluting with EtOAc/heptane $(0-80 \%)$ to afford the title compound 163-BP1-DZ (67 mg, $47 \%$ yield) as a white solid. ${ }^{1} \mathrm{H} N M R\left(400 \mathrm{MHz} \mathrm{CDCl}_{3}\right) \delta 7.82-7.78(\mathrm{~m}, 2 \mathrm{H}), 7.78-7.74(\mathrm{~m}, 2 \mathrm{H}), 7.73-$ $7.69(\mathrm{~m}, 2 \mathrm{H}), 7.50-7.47(\mathrm{~m}, 2 \mathrm{H}), 7.47-7.43(\mathrm{~m}, 2 \mathrm{H}), 7.30(\mathrm{~d}, J=8.1 \mathrm{~Hz}, 2 \mathrm{H}), 6.34$ (br. s., $1 \mathrm{H}), 5.24$ (br. s., $1 \mathrm{H}), 4.68-4.42(\mathrm{~m}, 3 \mathrm{H}), 2.23-2.08(\mathrm{~m}, 3 \mathrm{H}), 2.00(\mathrm{t}, J=2.5 \mathrm{~Hz}, 1 \mathrm{H}), 1.48-1.37(\mathrm{~m}, 1 \mathrm{H})$; LRMS (M+H) 603.2; HPLC Purity: > 99\%.
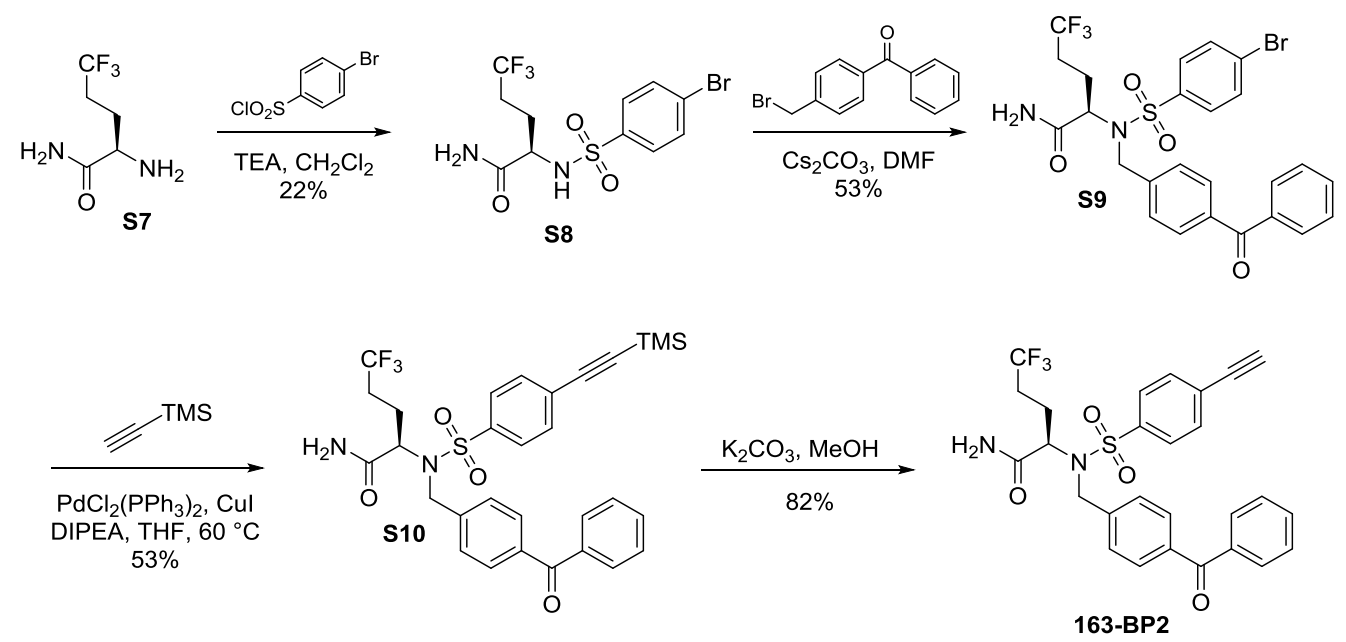

(R)-2-((4-bromophenyl)sulfonamido)-5,5,5-trifluoropentanamide (S8): To a solution of $\mathbf{S 7 ^ { 6 }}$ (235 $\mathrm{mg}$, $1.14 \mathrm{mmol}$ ) in $\mathrm{CH}_{2} \mathrm{Cl}_{2}(5.4 \mathrm{~mL}$ ) was added triethylamine ( $356 \mathrm{mg}, 0.49 \mathrm{~mL}, 3.41 \mathrm{mmol}$ ) followed by 4bromobenzenesulfonyl chloride $(320 \mathrm{mg}, 1.25 \mathrm{mmol}$ ). The reaction mixture was stirred at room temperature for 15 minutes upon which the reaction was judged complete by LCMS. The reaction mixture was quenched with saturated $\mathrm{NaHCO}_{3}$ and then extracted with $\mathrm{CH}_{2} \mathrm{Cl}_{2}$. The organic fraction was dried with anhydrous $\mathrm{MgSO}_{4}$, filtered and concentrated under reduced pressure. The crude residue was purified by silica gel flash chromatography eluting with EtOAc/Heptane $(20-100 \%)$ to afford the title compound $\mathbf{S 8}$ (98 mg, 22\% yield) as a solid. ${ }^{1} \mathrm{H}$ NMR (400 MHz, $\left.\mathrm{CDCl}_{3}\right) \delta 7.73-7.65(\mathrm{~m}, 4 \mathrm{H}), 5.61$ (br. s., $1 \mathrm{H}), 5.43(\mathrm{~d}, J=6.9 \mathrm{~Hz}, 1 \mathrm{H}), 5.35$ (br. s., $1 \mathrm{H}), 3.84-3.77(\mathrm{~m}, 1 \mathrm{H}), 2.26-2.14(\mathrm{~m}, 2 \mathrm{H}), 2.10-1.99(\mathrm{~m}, 1 \mathrm{H})$, $1.86-1.75(\mathrm{~m}, 1 \mathrm{H}) ;$ LRMS $(\mathrm{M}+\mathrm{H}) 389.1$.

(R)-2-(( $N$-(4-benzoylbenzyl)-4-bromophenyl)sulfonamido)-5,5,5-trifluoropentanamide (S9): To a solution of S8 (98 mg, $0.25 \mathrm{mmol}$ ) and 4-(bromomethyl)benzophenone (121 mg, $0.44 \mathrm{mmol})$ in DMF $(0.88 \mathrm{~mL})$ was added $\mathrm{Cs}_{2} \mathrm{CO}_{3}(290 \mathrm{mg}, 0.88 \mathrm{mmol})$ and the reaction mixture was stirred at room temperature for 1 hour. The mixture was diluted with EtOAc and washed with water $(4 \times 10 \mathrm{~mL})$. The combined organic fraction was dried with anhydrous $\mathrm{Na}_{2} \mathrm{SO}_{4}$, filtered and concentrated under reduced pressure. The crude residue was purified by silica gel flash chromatography eluting with EtOAc/Heptane $(10-100 \%)$ to afford the title compound $\mathbf{S 9}$ (110 mg, 43\% yield) as a white solid. ${ }^{1} \mathrm{H}$ NMR (400 MHz, $\left.\mathrm{CDCl}_{3}\right) \delta 7.80-7.71(\mathrm{~m}, 6 \mathrm{H}), 7.70-7.61(\mathrm{~m}, 3 \mathrm{H}), 7.52-7.42(\mathrm{~m}, 4 \mathrm{H}), 6.22$ (br. s., $\left.1 \mathrm{H}\right), 5.27$ (br. s., $\left.1 \mathrm{H}\right)$, $4.63-4.48(\mathrm{~m}, 2 \mathrm{H}), 4.41-4.35(\mathrm{~m}, 1 \mathrm{H}), 2.24-2.09(\mathrm{~m}, 1 \mathrm{H}), 2.04-1.94(\mathrm{~m}, 1 \mathrm{H}), 1.90-1.76(\mathrm{~m}, 1 \mathrm{H})$, $1.51-1.45(\mathrm{~m}, 1 \mathrm{H})$; LRMS $(\mathrm{M}+\mathrm{H})$ 583.2. 
(R)-2-((N-(4-benzoylbenzyl)-4-((trimethylsilyl)ethynyl)phenyl)sulfonamido)-5,5,5-trifluoropentanamide (S10): To a solution of $\mathbf{S 9}$ (171 mg, $0.29 \mathrm{mmol}$ ) in THF (3 mL) was added trimethylsilylacetylene (33 mg, $0.34 \mathrm{mmol}), \mathrm{PdCl}_{2}\left(\mathrm{PPh}_{3}\right)_{2}(10.7 \mathrm{mg}, 0.0150 \mathrm{mmol})$, Cul $(2.9 \mathrm{mg}, 0.0150 \mathrm{mmol})$ and DIPEA (114 mg, 0.879 $\mathrm{mmol}$ ). The reaction was heated to $60^{\circ} \mathrm{C}$ for 20 hours and then the mixture was concentrated under reduced pressure. The crude residue was purified by silica gel flash chromatography eluting with EtOAc/Heptane $(10-100 \%)$ to afford the title compound $\mathbf{S 1 0}\left(94 \mathrm{mg}, 53 \%\right.$ yield) as a solid. ${ }^{1} \mathrm{H}$ NMR $\left(400 \mathrm{MHz}, \mathrm{CDCl}_{3}\right) \delta 7.80-7.68(\mathrm{~m}, 6 \mathrm{H}), 7.62-7.56(\mathrm{~m}, 3 \mathrm{H}), 7.52-7.42(\mathrm{~m}, 4 \mathrm{H}), 6.19$ (br. s., $\left.1 \mathrm{H}\right), 5.23$ (br. s., $1 \mathrm{H}), 4.60-4.49(\mathrm{~m}, 2 \mathrm{H}), 4.37(\mathrm{t}, J=7.1 \mathrm{~Hz}, 1 \mathrm{H}), 2.20-2.08(\mathrm{~m}, 1 \mathrm{H}), 2.03-1.92(\mathrm{~m}, 1 \mathrm{H}), 1.89-$ $1.72(\mathrm{~m}, 1 \mathrm{H}), 1.50-1.45(\mathrm{~m}, 1 \mathrm{H}), 0.27(\mathrm{~s}, 9 \mathrm{H})$; LRMS $(\mathrm{M}+\mathrm{H}) 601.4$.

(R)-2-((N-(4-benzoylbenzyl)-4-ethynylphenyl)sulfonamido)-5,5,5-trifluoropentanamide (163-BP2): To a solution of $\mathbf{S 1 0}(94 \mathrm{mg}, 0.16 \mathrm{mmol})$ in $\mathrm{MeOH}(3.2 \mathrm{~mL})$ was added $\mathrm{K}_{2} \mathrm{CO}_{3}(50 \mathrm{mg}, 0.36 \mathrm{mmol})$ in one portion and the reaction mixture was stirred at room temperature for 1 hour upon which the reaction was judged complete by LCMS. The reaction mixture was concentrated under reduced pressure and EtOAc was added and washed with water. The organic fraction was dried with anhydrous $\mathrm{Na}_{2} \mathrm{SO}_{4}$, filtered and concentrated under reduced pressure. The crude residue was purified by silica gel flash chromatography eluting with EtOAc/Heptane $(0-100 \%)$ to afford the title compound 163-BP2 (23 mg, $82 \%$ yield) as a white solid. ${ }^{1} \mathrm{H} \mathrm{NMR}\left(400 \mathrm{MHz}, \mathrm{CDCl}_{3}\right) \delta 7.82-7.68(\mathrm{~m}, 6 \mathrm{H}), 7.63(\mathrm{~d}, J=8.5 \mathrm{~Hz}, 2 \mathrm{H}), 7.59$ $(\mathrm{d}, J=7.5 \mathrm{~Hz}, 1 \mathrm{H}), 7.53-7.42(\mathrm{~m}, 4 \mathrm{H}), 6.22$ (br. s., $1 \mathrm{H}), 5.34$ (br. s., $1 \mathrm{H}), 4.65-4.47(\mathrm{~m}, 2 \mathrm{H}), 4.38(\mathrm{dd}, J=$ 7.0, 8.2 Hz, 1H), $3.31(\mathrm{~s}, 1 \mathrm{H}), 2.15(\mathrm{dtd}, J=5.6,8.8,14.0 \mathrm{~Hz}, 1 \mathrm{H}), 2.05-1.90(\mathrm{~m}, 1 \mathrm{H}), 1.88-1.73(\mathrm{~m}, 1 \mathrm{H})$, $1.56-1.43(\mathrm{~m}, 1 \mathrm{H})$; LRMS $(\mathrm{M}+\mathrm{H}) 529.4$.
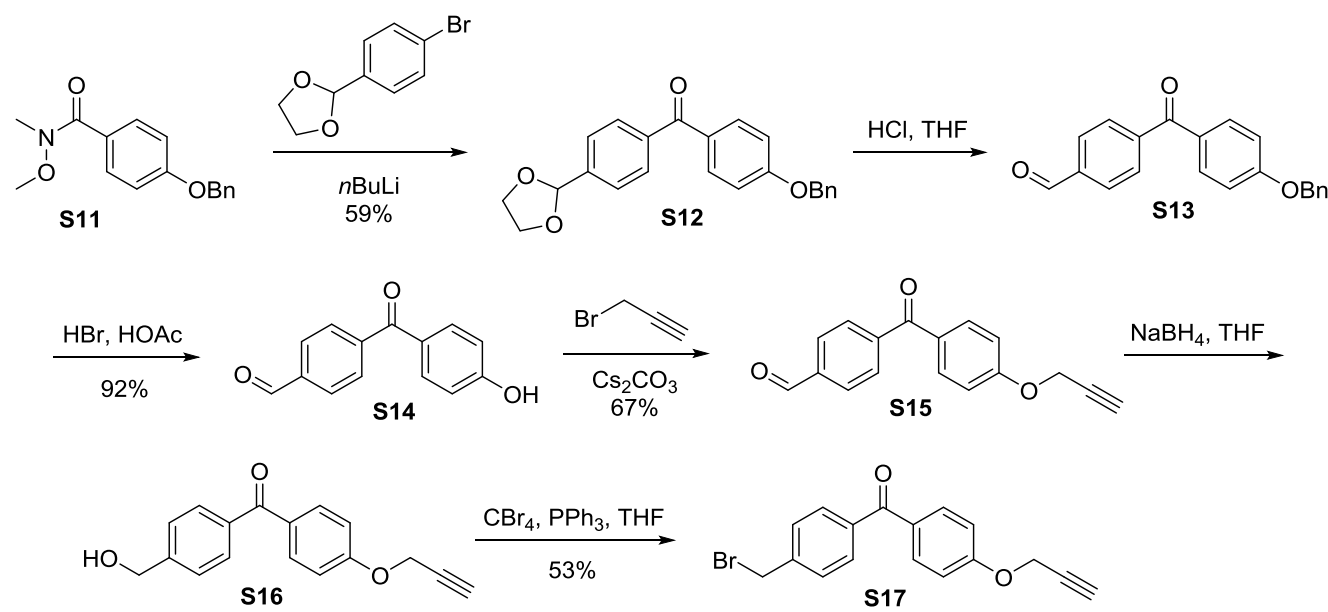

(4-(1,3-dioxolan-2-yl)phenyl)(4-(benzyloxy)phenyl)methanone (S12): To a solution of 2-(4-

bromophenyl)-1,3-dioxolane (20000 mg, $87 \mathrm{mmol}$ ) in THF $(300 \mathrm{~mL}$ ) was added dropwise $2.5 \mathrm{M} \mathrm{nBuLi}$ (36 $\mathrm{mL}, 87 \mathrm{mmol}$ ) at $-70{ }^{\circ} \mathrm{C}$. Then the mixture was stirred at $-70^{\circ} \mathrm{C}$ for 40 minutes. A solution of $\mathbf{S 1 1}{ }^{7}$ (11800 $\mathrm{mg}, 43.5 \mathrm{mmol})$ in THF $(100 \mathrm{~mL})$ was added dropwise, after addition, the mixture was stirred at $-70{ }^{\circ} \mathrm{C}$ for 1 hour. TLC (Petroleum ether/EtOAC=3/1) showed the reaction was completed. The mixture was quenched with saturated $\mathrm{NH}_{4} \mathrm{Cl}(50 \mathrm{~mL})$ and extracted with EtOAc $(2 \times 100 \mathrm{~mL})$, the organic layer was concentrated under reduced pressure and the residue was purified by silica gel flash chromatography to afford the title compound $\mathbf{S 1 2}(10000 \mathrm{mg}, 59 \%)$ as an off-white solid. ${ }^{1} \mathrm{H} \mathrm{NMR}\left(400 \mathrm{MHz}, \mathrm{CDCl}_{3}\right) \delta 7.81$ 
(d, $J=8.8 \mathrm{~Hz}, 2 \mathrm{H}), 7.75(\mathrm{~d}, J=8.1 \mathrm{~Hz}, 2 \mathrm{H}), 7.58(\mathrm{~d}, J=8.1 \mathrm{~Hz}, 2 \mathrm{H}), 7.44-7.32(\mathrm{~m}, 5 \mathrm{H}), 7.02(\mathrm{~d}, J=8.8 \mathrm{~Hz}$, $2 \mathrm{H}), 5.88(\mathrm{~s}, 1 \mathrm{H}), 5.14(\mathrm{~s}, 2 \mathrm{H}), 4.13-4.07(\mathrm{~m}, 4 \mathrm{H})$; LRMS $(\mathrm{M}+\mathrm{H}) 361.0$.

4-(4-(benzyloxy)benzoyl)benzaldehyde (S13): To a solution of compound S12 (10000 mg, $27.7 \mathrm{mmol}$ ) in THF $(200 \mathrm{~mL})$ was added concentrated $\mathrm{HCl}(30 \mathrm{~mL})$, then the mixture was refluxed for 4 hours. TLC (Petroleum ether/EtOAc=3/1) indicated the reaction was completed. The mixture was concentrated in vacuo and the residue was dissolved in EtOAc $(150 \mathrm{~mL})$, washed with saturated $\mathrm{NaHCO}_{3}$ and brine, the organic layer was dried over $\mathrm{Na}_{2} \mathrm{SO}_{4}$ and concentrated under reduced pressure to afford the title compound S13 (9000 $\mathrm{mg}$ ) as a yellow oil which was used with no further purification.

4-(4-hydroxybenzoyl)benzaldehyde (S14): A solution of compound $\mathbf{S 1 3}(9000 \mathrm{mg}, 28 \mathrm{mmol}$ ) in $\mathrm{HBr} / \mathrm{HOAC}(100 \mathrm{~mL})$ was stirred at room temperature for 3 hours. TLC (Petroleum ether/EtOAc=3/1) indicated the reaction was completed. The mixture was concentrated in vacuum, $\mathrm{H}_{2} \mathrm{O}(200 \mathrm{~mL})$ was added and the mixture was extracted with EtOAc $(2 \times 100 \mathrm{~mL})$, the organic layer was concentrated under reduced pressure and the residue was purified by silica gel flash chromatography to afford the title compound S14 (5800 mg, 92\%) as a yellow solid. ${ }^{1} \mathrm{H}$ NMR (400 MHz, DMSO- $\left.d_{6}\right) \delta 10.54(\mathrm{~s}, 1 \mathrm{H})$, $10.13(\mathrm{~s}, 1 \mathrm{H}), 8.05(\mathrm{~d}, J=8.1 \mathrm{~Hz}, 2 \mathrm{H}), 7.83(\mathrm{~d}, J=8.1 \mathrm{~Hz}, 2 \mathrm{H}), 7.68(\mathrm{~d}, J=8.7 \mathrm{~Hz}, 2 \mathrm{H}), 6.91(\mathrm{~d}, J=8.7 \mathrm{~Hz}$, 2H); LRMS (M-H) 225.2.

4-(4-(prop-2-yn-1-yloxy)benzoyl)benzaldehyde (S15): To a solution of compound S14 (5200 mg, 23 $\mathrm{mmol})$ in DMF $(200 \mathrm{~mL})$ was added $\mathrm{K}_{2} \mathrm{CO}_{3}(3200 \mathrm{mg}, 23 \mathrm{mmol})$ in one portion. Then the mixture was stirred at room temperature for 20 minutes. Propargyl bromide ( $2700 \mathrm{mg}, 23 \mathrm{mmol}$ ) was added and the mixture was stirred at room temperature for 2 hours. TLC (Petroleum ether/EtOAc=3/1) indicated the reaction was completed. $\mathrm{H}_{2} \mathrm{O}(200 \mathrm{~mL})$ was added and the mixture was extracted with EtOAc $(2 \times 100$ $\mathrm{mL}$ ), the organic layer was concentrated under reduced pressure and the residue was purified by silica gel flash chromatography to afford the title compound $\mathbf{S 1 5}(4000 \mathrm{mg}, 67 \%)$ as an off-white solid. ${ }^{1} \mathrm{H}$ $\operatorname{NMR}\left(400 \mathrm{MHz}, \mathrm{CDCl}_{3}\right) \delta 10.12(\mathrm{~s}, 1 \mathrm{H}), 7.98(\mathrm{~d}, J=8.1 \mathrm{~Hz}, 2 \mathrm{H}), 7.87(\mathrm{~d}, J=8.1 \mathrm{~Hz}, 2 \mathrm{H}), 7.82(\mathrm{~d}, J=8.8 \mathrm{~Hz}$, $2 \mathrm{H}), 7.06(\mathrm{~d}, J=8.8 \mathrm{~Hz}, 2 \mathrm{H}), 4.78(\mathrm{~s}, 2 \mathrm{H}), 2.56(\mathrm{~s}, 1 \mathrm{H})$; LRMS $(\mathrm{M}+\mathrm{H})$ 265.2; HPLC Purity: 98.6\%.

(4-(hydroxymethyl)phenyl)(4-(prop-2-yn-1-yloxy)phenyl)methanone (S16): To a solution of S15 (5000 $\mathrm{mg}, 18.9 \mathrm{mmol})$ in THF (250 mL) was added sodium borohydride $(720 \mathrm{mg}, 18.4 \mathrm{mmol})$ portion-wise at 0 ${ }^{\circ} \mathrm{C}$ and stirred for 30 minutes at room temperature. TLC indicated $\mathbf{S 1 5}$ was consumed. The mixture was quenched with saturated $\mathrm{NH}_{4} \mathrm{Cl}$ solution $(100 \mathrm{~mL})$ and extracted with EtOAc $(2 \times 150 \mathrm{~mL})$. The combined organic solution was dried over $\mathrm{Na}_{2} \mathrm{SO}_{4}$ and concentrated under reduced pressure to afford the title compound $\mathbf{S 1 6}$ (5000 $\mathrm{mg}$ ) which was used in the next step without purification.

(4-(bromomethyl)phenyl)(4-(prop-2-yn-1-yloxy)phenyl)methanone (S17): To the solution of S16 (5000 $\mathrm{mg}, 18.8 \mathrm{mmol})$ in $\mathrm{CH}_{2} \mathrm{Cl}_{2}(150 \mathrm{~mL})$ was added $\mathrm{PPh}_{3}(5900 \mathrm{mg}, 22.5 \mathrm{mmol})$, followed by the addition of $\mathrm{CBr}_{4}$ (7460 mg, $22.5 \mathrm{mmol}$ ) and the reaction was stirred at the room temperature for 3 hours. TLC showed complete consumption of $\mathbf{S 1 6}$, the reaction was evaporated and the crude mixture was dissolved in EtOAc and washed with $\mathrm{NaHCO}_{3}(\mathrm{aq})$ and $\mathrm{H}_{2} \mathrm{O}$ and then brine solution, dried over anhydrous $\mathrm{Na}_{2} \mathrm{SO}_{4}$ and concentrated under reduced pressure and the crude compound was purified by silica gel flash chromatography to afford the title compound S17 (3300 mg, 53\%) as an off-white solid. ${ }^{1} \mathrm{H}$ NMR 
$\left(400 \mathrm{MHz}, \mathrm{CDCl}_{3}\right) \delta 7.82(\mathrm{~d}, J=8.7 \mathrm{~Hz}, 2 \mathrm{H}), 7.73(\mathrm{~d}, J=8.8 \mathrm{~Hz}, 2 \mathrm{H}), 7.49(\mathrm{~d}, J=8.8 \mathrm{~Hz}, 2 \mathrm{H}), 7.04(\mathrm{~d}, J=8.7$ $\mathrm{Hz}, 2 \mathrm{H}), 4.77(\mathrm{~s}, 2 \mathrm{H}), 4.53(\mathrm{~s}, 2 \mathrm{H}), 2.56(\mathrm{~s}, 1 \mathrm{H})$; LRMS (M+H) 328.0; HPLC Purity: 95.1\%

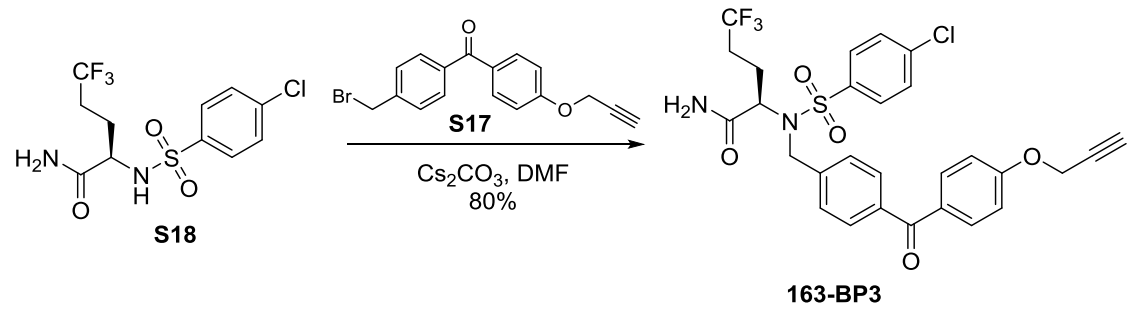

(R)-2-((4-chloro-N-(4-(4-(prop-2-yn-1-yloxy)benzoyl)benzyl)phenyl)sulfonamido)-5,5,5-

trifluoropentanamide (163-BP3): A solution of $\mathbf{S} 18^{6}(57 \mathrm{mg}, 0.16 \mathrm{mmol})$ in anhydrous DMF (0.83 $\left.\mathrm{mL}\right)$ was cooled to $0{ }^{\circ} \mathrm{C}$. To this solution was added $\mathbf{S} 17$ ( $60 \mathrm{mg}, 0.18 \mathrm{mmol}$ ) and $\mathrm{Cs}_{2} \mathrm{CO}_{3}(65 \mathrm{mg}, 0.20 \mathrm{mmol}$ ) and the mixture was then warmed to room temperature. The reaction was judged complete by TLC analysis ( 4 hours) and the reaction mixture was diluted with EtOAc $(10 \mathrm{~mL})$ and washed with water (15 $\mathrm{mL})$. The aqueous layer was back-extracted with EtOAc $(3 \times 10 \mathrm{~mL})$ and the combined organics were washed with water $(10 \mathrm{~mL}), 1 \mathrm{M} \mathrm{LiCl}(10 \mathrm{~mL})$ and brine $(10 \mathrm{~mL})$ before being dried with anhydrous $\mathrm{Na}_{2} \mathrm{SO}_{4}$, filtered and concentrated under reduced pressure. The resulting crude residue was purified by silica gel flash chromatography eluting with EtOAc/heptane (10 - 40\%) to afford the title compound 163BP3 (78 mg, 80\% yield) as a white solid. ${ }^{1} \mathrm{H}$ NMR (400 MHz, $\left.\mathrm{CD}_{3} \mathrm{OD}\right) \delta 7.86-7.79(\mathrm{~m}, 2 \mathrm{H}), 7.80-7.72$ $(\mathrm{m}, 2 \mathrm{H}), 7.67-7.62(\mathrm{~m}, 2 \mathrm{H}), 7.61-7.56(\mathrm{~m}, 2 \mathrm{H}), 7.56-7.51(\mathrm{~m}, 2 \mathrm{H}), 7.13-7.05(\mathrm{~m}, 2 \mathrm{H}), 4.84(\mathrm{~s}, 4 \mathrm{H})$, $4.56(\mathrm{dd}, J=5.9,8.6 \mathrm{~Hz}, 1 \mathrm{H}), 3.01(\mathrm{t}, J=2.3 \mathrm{~Hz}, 1 \mathrm{H}), 2.16-1.90(\mathrm{~m}, 3 \mathrm{H}), 1.75-1.63(\mathrm{~m}, 1 \mathrm{H}) ;{ }^{13} \mathrm{C} \mathrm{NMR}$ (100 MHz, CD $\left.{ }_{3} \mathrm{OD}\right) \delta 197.2,173.5,163.1,143.8,140.6,140.0,138.7,133.6,131.9,131.0,130.6,130.4$, 129.7, 127.2 (q, $\left.{ }^{1} \mathrm{~J}_{\mathrm{CF}}=275.1 \mathrm{~Hz}\right), 115.8,79.3,77.6,60.2,57.0,49.7,31.8\left(\mathrm{q},{ }^{2} \mathrm{~J}_{\mathrm{CF}}=29.3 \mathrm{~Hz}\right.$ ), $24.5 ;{ }^{19} \mathrm{~F} \mathrm{NMR}$ (377 MHz, CD $\mathrm{OD}$ ) $\delta-68.00\left(\mathrm{t}, J=10.2 \mathrm{~Hz}, 3 \mathrm{~F}\right.$ ); HRMS calcd for $\mathrm{C}_{28} \mathrm{H}_{25} \mathrm{ClF}_{3} \mathrm{~N}_{2} \mathrm{O}_{5} \mathrm{~S}(\mathrm{M}+\mathrm{H})$ 593.1119, found 593.1123; HPLC Purity: 95\%.
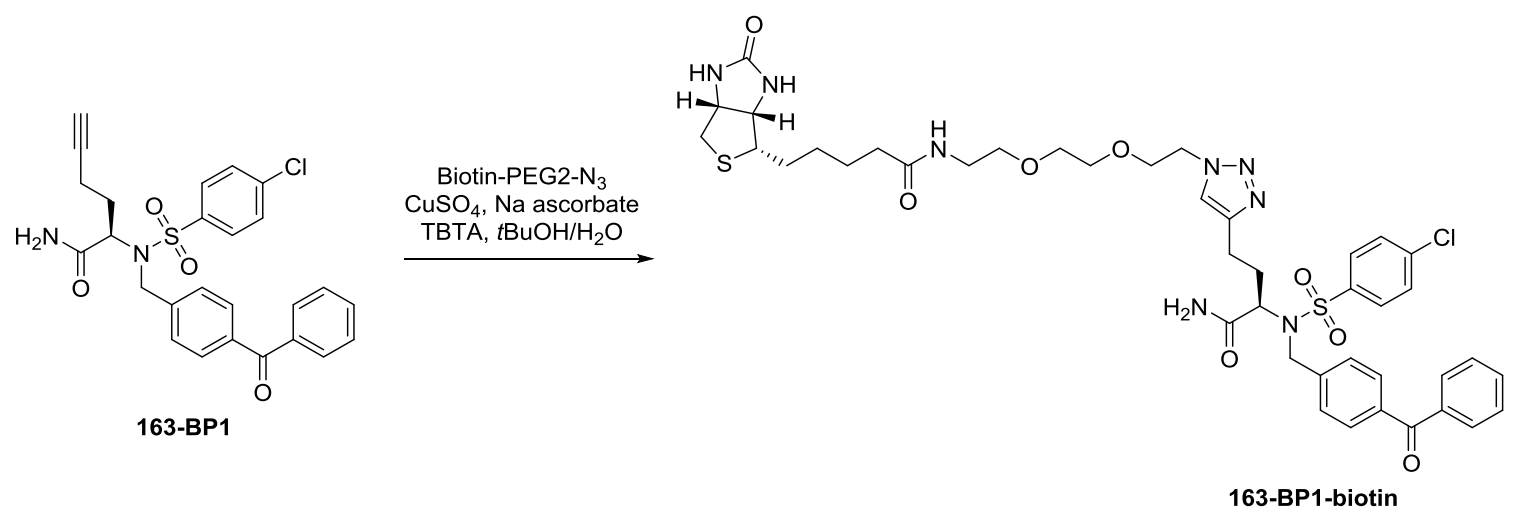

N-(2-(2-(2-(4-((R)-4-amino-3-((N-(4-benzoylbenzyl)-4-chlorophenyl)sulfonamido)-4-oxobutyl)-1H-1,2,3triazol-1-yl)ethoxy)ethoxy)ethyl)-5-((3aS,4S,6aR)-2-oxohexahydro-1H-thieno[3,4-d]imidazol-4yl)pentanamide (163-BP1-biotin): A solution of 163-BP1 (4.2 mg, $8.5 \mu \mathrm{mol})$, biotin-PEG2- $\mathrm{N}_{3}{ }^{8}(3.4 \mathrm{mg}$, $8.5 \mu \mathrm{mol})$, copper sulfate pentahydrate $(0.1 \mathrm{mg}, 0.42 \mu \mathrm{mol})$, sodium ascorbate $(0.33 \mathrm{mg}, 1.68 \mu \mathrm{mol})$ and Tris[(1-benzyl-1H-1,2,3-triazol-4-yl)methyl]amine ligand $(0.22 \mathrm{mg}, 0.42 \mu \mathrm{mol})$ in $\mathrm{tBuOH} / \mathrm{H}_{2} \mathrm{O}(50: 50)$ was 
stirred at room temperature overnight. The mixture was filtered and purified by HPLC to afford the title compound 163-BP1-biotin as a white solid. ( $\mathrm{m} / \mathrm{z}=929.16$ for $\mathrm{Cl}^{-}$salt, $\mathrm{m} / \mathrm{z}=917.19$ for $\mathrm{Na}^{+}$salt).

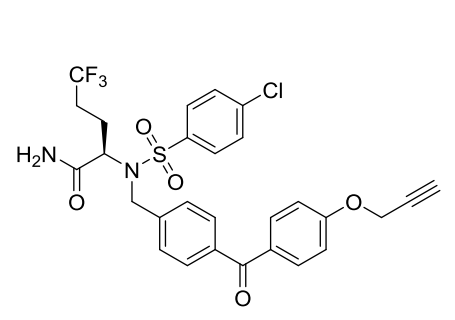

163-BP3

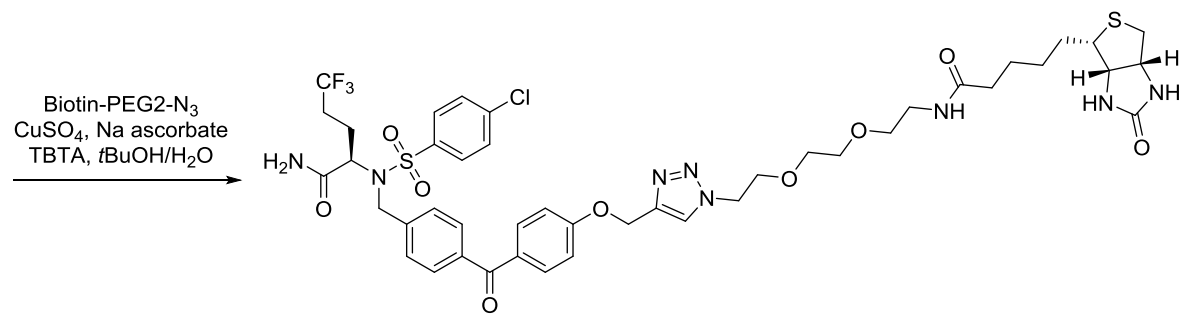

163-BP3-biotin

(R)-2-((4-chloro-N-(4-(4-((1-)(2-(2-(2-(5-)(3aS,4S,6aR)-2-oxohexahydro-1H-thieno[3,4-d]imidazol-4yl)pentanamido)ethoxy)ethoxy)ethyl)-1H-1,2,3-triazol-4-

yl)methoxy)benzoyl)benzyl)phenyl)sulfonamido)-5,5,5-trifluoropentanamide (163-BP3-biotin): A solution of 163-BP3 (5.0 mg, $8.5 \mu \mathrm{mol})$, biotin-PEG2- $\mathrm{N}_{3}(3.4 \mathrm{mg}, 8.5 \mu \mathrm{mol})$, copper sulfate pentahydrate $(0.1 \mathrm{mg}, 0.42 \mu \mathrm{mol})$, sodium ascorbate $(0.33 \mathrm{mg}, 1.68 \mu \mathrm{mol})$ and Tris[(1-benzyl-1H-1,2,3-triazol-4$\mathrm{yl}$ )methyl]amine ligand $(0.22 \mathrm{mg}, 0.42 \mu \mathrm{mol})$ in $\mathrm{tBuOH} / \mathrm{H}_{2} \mathrm{O}(50: 50)$ was stirred at room temperature overnight. The mixture was filtered and purified by HPLC to afford the title compound 163-BP3-biotin as a white solid. ( $\mathrm{m} / \mathrm{z}=1027.4$ for $\mathrm{Cl}^{-}$salt, $\mathrm{m} / \mathrm{z}=1015.49$ for $\mathrm{Na}^{+}$salt).
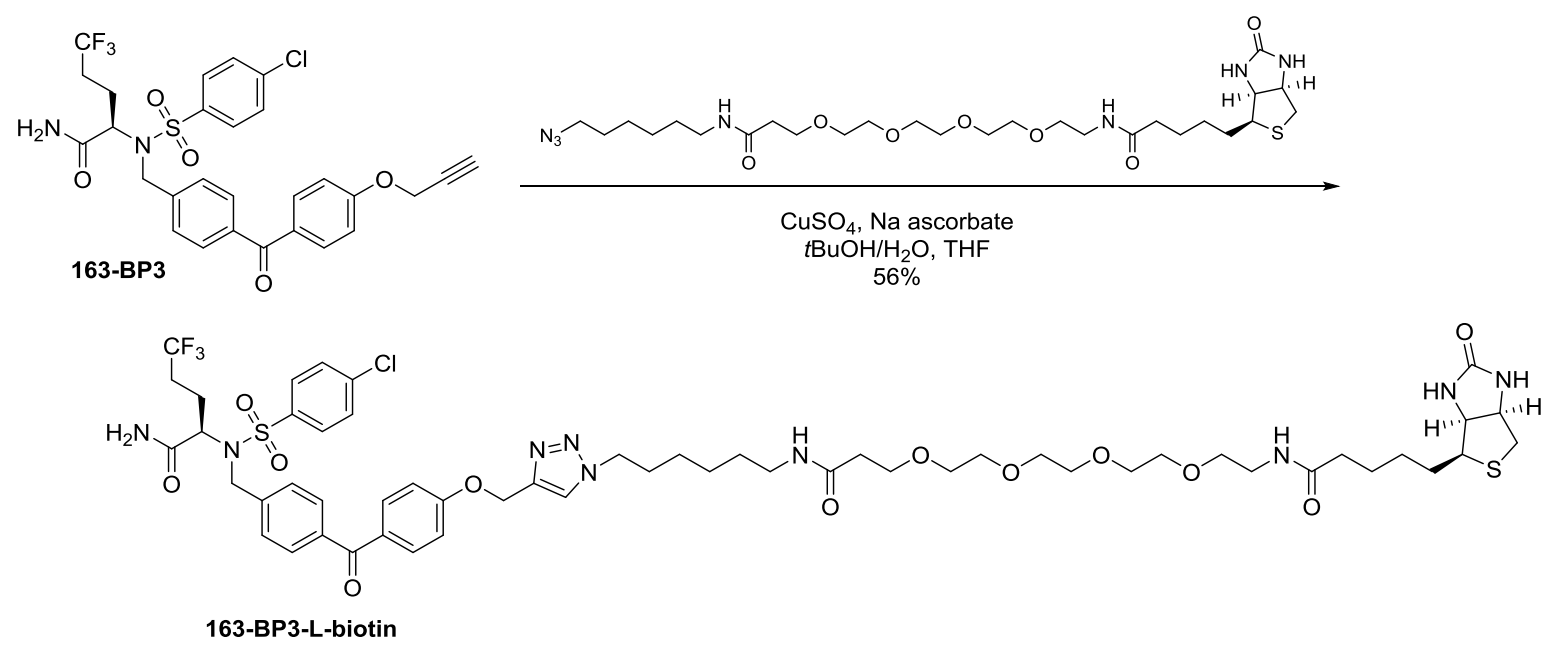

$N-(6-(4-)(4-(4-)((N-)(R)-1-a m i n o-5,5,5-t r i f l u o r o-1-o x o p e n t a n-2-y l)-4-$

chlorophenyl)sulfonamido)methyl)benzoyl)phenoxy)methyl)-1H-1,2,3-triazol-1-yl)hexyl)-1-(5((3aS,4S,6aR)-2-oxohexahydro-1H-thieno[3,4-d]imidazol-4-yl)pentanamido)-3,6,9,12-

tetraoxapentadecan-15-amide (163-BP3-L-biotin): To the mixture of 163-BP3 (35 mg, $0.059 \mathrm{mmol})$ and biotin-PEG4- $\mathrm{N}_{3}{ }^{9}(36 \mathrm{mg}, 0.059 \mathrm{mmol})$ in $t \mathrm{BuOH}-\mathrm{H}_{2} \mathrm{O}(1: 1,0.75 \mathrm{~mL})$ and THF $(0.75 \mathrm{~mL})$ were added copper sulfate pentahydrate $(1.5 \mathrm{mg}, 0.0059 \mathrm{mmol})$ and sodium ascorbate $\left(1 \mathrm{M}\right.$ in $\mathrm{H}_{2} \mathrm{O}, 5$ drops) at room temperature and stirred for 18 hours. TLC indicated complete consumption of starting material and the reaction mixture was concentrated under reduced pressure. The mixture was diluted with water and extracted with EtOAc $(2 x)$. The combined organic fraction was washed with water and brine, dried with anhydrous $\mathrm{Na}_{2} \mathrm{SO}_{4}$, and concentrated under reduced pressure. The crude residue was purified by 
preparative TLC to afford the title compound 163-BP3-L-biotin (40mg, 56\% yield) as an off-white solid. ${ }^{1} \mathrm{H}$ NMR $\left(400 \mathrm{MHz}, \mathrm{CD}_{3} \mathrm{OD}\right) \delta=8.12(\mathrm{~s}, 1 \mathrm{H}), 7.85(\mathrm{~d}, J=7.4 \mathrm{~Hz}, 2 \mathrm{H}), 7.79(\mathrm{~d}, J=7.6 \mathrm{~Hz}, 2 \mathrm{H}), 7.68-7.64$ $(\mathrm{m}, 2 \mathrm{H}), 7.61-7.47(\mathrm{~m}, 4 \mathrm{H}), 7.16(\mathrm{~d}, J=7.6 \mathrm{~Hz}, 2 \mathrm{H}), 5.30(\mathrm{~s}, 2 \mathrm{H}), 4.82(\mathrm{~s}, 2 \mathrm{H}), 4.60-4.53(\mathrm{~m}, 1 \mathrm{H}), 4.51-$ $4.40(\mathrm{~m}, 3 \mathrm{H}), 4.29(\mathrm{dd}, J=4.4,7.5 \mathrm{~Hz}, 1 \mathrm{H}), 3.71(\mathrm{t}, J=5.8 \mathrm{~Hz}, 2 \mathrm{H}), 3.61(\mathrm{~d}, J=6.7 \mathrm{~Hz}, 12 \mathrm{H}), 3.53(\mathrm{t}, J=5.2$ $\mathrm{Hz}, 2 \mathrm{H}), 3.35(\mathrm{t}, J=5.5 \mathrm{~Hz}, 2 \mathrm{H}), 3.22-3.12(\mathrm{~m}, 3 \mathrm{H}), 2.91(\mathrm{dd}, J=4.2,12.8 \mathrm{~Hz}, 1 \mathrm{H}), 2.69(\mathrm{~d}, J=12.7 \mathrm{~Hz}$, $1 \mathrm{H}), 2.42(\mathrm{t}, J=5.9 \mathrm{~Hz}, 2 \mathrm{H}), 2.21(\mathrm{t}, J=7.2 \mathrm{~Hz}, 2 \mathrm{H}), 2.16-1.85(\mathrm{~m}, 6 \mathrm{H}), 1.81-1.53(\mathrm{~m}, 5 \mathrm{H}), 1.53-1.21$ (m, 7H); LRMS (M+H) 1208.6; HPLC Purity: 96\%.

\footnotetext{
${ }^{1}$ Crump, C. J., Castro, S. V., Wang, F., Pozdnyakov, N., Ballard, T. E., Sisodia, S. S., Bales, K. R., Johnson, D. S., and Li, Y. M. (2012), Biochemistry 51, 7209-7211.

${ }^{2} \mathrm{TCl}$ America

${ }^{3}$ Belluti, F., Piazzi, L., Bisi, A., Gobbi, S., Bartolini, M., Cavalli, A., Valenti, P., Rampa, A. (2009), Eur. J. Med. Chem. 44, 1341-1348.

${ }^{4}$ Yamazaki, Y., Yokoyama, A., Yokozawa, T. (2012) J. Polym. Sci. Part A: Polym. Chem. 50, 3648-3655.

${ }^{5}$ Guo, L., Hajipour, A. R., Gavala, M.L., Arbabian, M., Martemyanov, K. A., Vadim, Y. A., Ruoho, A. E. (2005) Bioconjugate Chem. 16, 685-693.

${ }^{6}$ Starrett, J. E. Jr., Gillman, K. W., Olson, R. E. US 20090111858

${ }^{7}$ Verhoest, P. R., Helal, C. J., Hoover, D. J., Humphrey, J. M. WO 2006072828

${ }^{8}$ ChemPep Inc.

${ }^{9}$ ThermoFisher Scientific
} 